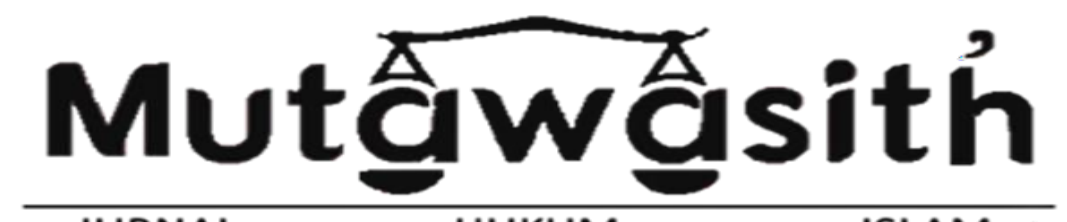

\begin{tabular}{|l|c|c|}
\cline { 2 - 3 } \multicolumn{1}{c|}{ JURNAL } & HUKUM & ISLAM \\
\hline $\begin{array}{l}\text { Vol. 3. No. } 2 \text { (2020) 07- } \\
12\end{array}$ & E-ISSN: : 2723-4681 & P-ISSN: 2722-2764 \\
\hline \multicolumn{2}{|c|}{ Published online on the journal's website: } \\
http://jurnal.iailm.ac.id/index.php/mutawasith
\end{tabular}

\title{
Konsep Jual Beli Dalam Perspektif Al-Quran Dan Al-Sunnah (Urgensitas Penerapan Prinsip Halalan Thayyiban sebagai indikator dalam Mengukur Hukum Keabsahan terhadap Praktik Jual Beli)
}

\author{
Neli Purnamasari, Acep Faizal Ramdan \\ Program Pascasarjana, Universitas Islam Negeri Sunan Gunung Djati Bandung, \\ Indonesia \\ nelipurnamasari86@gmail.com; ramdanafaizal@gmail.com
}

\begin{tabular}{|c|c|c|}
\hline Received: & Revised: & Published: \\
\hline 04-10-2020 & $06-11-2020$ & $15-12-2020$ \\
\hline \multicolumn{2}{|c|}{ DOI: https://doi.org/ 10.47971/mjhi.v3i2.215 } \\
\hline
\end{tabular}

\begin{abstract}
This research is based on the fact that most indonesian Muslim communities do not yet understand the concept of good and true trade according to the perspective of the Quran and Al-Sunnah. The concept of buying and selling that they understand only for the fulfillment of needs in satisfying the appetite (buyer), and only to pursue the biggest profit (seller), without considering the maslahat and mafsadatnya. The purpose of this research is to describe the urgency of the principle of halalan thayyiban in the concept of buying and selling according to the Quran and AlSunnah. The method used is descriptive, by presenting the concept of buying and selling according to the perspective of the Quran and Al-Sunnah, while the data collection technique is a study of libraries from several journals and several books related to this research. The results showed that the sale of halalan tayyiban was a necessity because it was part of the terms of the trade. The trade transaction is not halal and good then the sale becomes ghair saheeh or bathi. The basis of the law of buying and selling with halalan thayyiban is surah al-Baqarah verse 172-173 and hadeeth narrated by Al-Bukhaari Muslim (Mutafaq 'alaih) in the book of Bulughul Maram hadeeth to 801, on prohibition of trade.
\end{abstract}

Keywords: Qur'an, Al-Sunnah, Buy, Sell, Halal 


\begin{abstract}
Abstrak
Penelitian ini dilatarbelakangi oleh fakta bahwa mayoritas muslim Indonesia belum memahami konsep jual beli yang baik dan benar perspektif Al-Quran dan Al-Sunnah. Konsep jual beli yang mereka pahami hanya untuk pemenuhan kebutuhan pembeli, dan hanya untuk mengejar keuntungan penjual, tanpa mempertimbangkan maslahat dan mafsadatnya. Tujuan penelitian ini adalah mendeskripsikan urgensi prinsip halalan thayyiban dalam konsep jual beli menurut Al-Quran dan Al-Sunnah. Metode yang digunakan adalah deskriptif, dengan cara memaparkan konsep jual beli menurut perspektif Al-Quran dan Al-Sunnah, sedangkan teknik pengumpulan datanya kajian pustaka dari beberapa jurnal dan beberapa buku yang berkaitan dengan penelitian ini. Hasil penelitian menunjukan bahwa bahwa jual beli yang halalan tayyiban itu menjadi suatu keharusan karena merupakan bagian dari syarat jual beli. Transaksi jual belinya yang tidak halal dan baik maka jual belinya menjadi ghair shahih atau bathi. Adapun dasar hukum jual beli dengan halalan thayyiban yaitu surat al-Baqarah ayat 172-173 serta hadits riwayat Bukhari Muslim (Mutafaq 'alaih) dalam kitab Bulughul Maram hadits ke 801, tentang larangan jual beli.
\end{abstract}

Kata kunci: Al-Qur'an, Al-Sunnah, Jual, Beli, Halal

\title{
PENDAHULUAN
}

Jual beli merupakan salah satu kegiatan rutinitas yang dilakukan masyarakat sehari-hari. Dalam melakukan transaksi jual beli menurut AlQuran dan Al-Sunnah, namun sayangnya hal tersebut dikesampingkan, dan ironisnya oleh orang Islam itu sendiri. Dalam hal ini, sebagian besar masyarakat akan memilih makanan atau minuman yang enak menurut pandangannya sendiri tanpa mempertimbangkan apakah makanan atau minuman tersebut halal atau tidak, dan apakah makanan atau minuman tersebut baik atau tidak untuk kesehatan, ini berarti sebagian masyarakat hanya mengejar kepuasan.

Seperti kasus di Indonesia, masih banyak masyarakat Indonesia yang membeli (mengkonsumsi) minuman beralkohol dan menjual minuman beralkohol. Hal ini bisa dilihat dari ringkasan hasil survei penyalahgunaan dan peredaran gelap narkoba dan minuman beralkohol dalam kelompok pelajar dan mahasiswa tahun 2016, menurut Endang Mulyani bahwa angka prevalensi orang yang mengkonsumsi minuman alkohol cenderung stagnan dalam 1 dekade terakhir yaitu dari 17\% (2006) menjadi 16\% (2016). Sedangkan Pada perguruan tinggi terjadi penurunan tajam dari 30\% menjadi 22\% dan kelompok SMA dari 21\% menjadi 17\% dalam satu dekade terakhir. Dan jika dilihat bagaimana pengaruh minum alkohol di kota dibandingkan dengan minum alkohol di kabupaten, bahwa Angka prevalensi minum 
alkohol di kota (16\%-18\%) lebih tinggi sedikit dibandingkan di kabupaten (13\%-15\%) dalam 10 tahun terakhir. ${ }^{1}$

Selain itu, masih banyak juga masyarakat Indonesia yang memproduksi minuman beralkohol, bisa dilihat dari data laporan analisis impor produk minuman beralkohol dalam pelabuhan tertentu, yang ditunjukan oleh tabel dibawah ini:

Tabel:

Perkembangan Nilai Produksi Industri Minuman

Beralkohol Indonesia

Tahun 2010-2013

\begin{tabular}{|c|c|c|c|c|c|}
\hline Nilai Produksi (Milyar Rp) & 2010 & 2011 & 2012 & 2013 & Trend (\%) '2010-2013 \\
\hline Minuman keras & $1,279.0$ & 778.7 & $1,617.2$ & 2,454.8 & $\beta 0.8$ \\
\hline Minuman Anggur dan sejenisnya & 107.6 & 211.9 & 106.3 & 139.0 & 42.3 \\
\hline Minuman Keras dari Malt dan Malt & 0.0 & 0.0 & 0.0 & p.o & \\
\hline Total Industri Minuman Beralkohol & $1,386.6$ & $990.6^{\prime}$ & $1,723.5^{\prime}$ & $2,893.8^{\prime}$ & 31.8 \\
\hline
\end{tabular}

Sumber: Kementerian Perindustrian (2016), diolah Puska Daglu

Seiring dengan peningkatan permintaan dan banyaknya produsen minuman beralkohol yang telah mencapai kapasitas produksi maksimum, perusahaan industri minuman beralkohol yang telah ada di Indonesia diizinkan untuk meningkatkan kapasitas produksinya sebagaimana Peraturan Menteri Perindustrian No. 63/M-IND/PER/7/2014. Pada akhir tahun 2014 perusahaan industri minuman beralkohol terdepan, Multi Bintang, telah menyelesaikan pembangunan pabrik ketiga di Jawa Timur dan dengan adanya pabrik baru tersebut menambah kapasitas produksi sekitar 500 ribu hektoliter. Pusat Pengkajian Perdagangan Luar Negeri, "Laporan Analisis Impor Produk Minuman Beralkohol Melalui Pelabuhan Tertentu" (Jakarta, 2016). Adanya pelegalan jual beli minuman beralkohol ini sangat ironis sekali, padahal pemimpin kita adalah seorang muslim setidaknya ada usaha untuk menghambat agar pengusaha tidak memproduksi minuman beralkohol, malah memberi kesempatan kepada pengusaha untuk memproduksi lebih banyak lagi dengan didirikannya pabrik di Jawa Timur. Padahal kalau dilihat dari maslahah atau tidaknya, sudah tentu banyak mafsadatnya.

\footnotetext{
${ }^{1}$ Endang Mulyani, Ringkasan Eksekutif Hasil Survei Penyahgunaan dan Peredaran Gelap Narkoba pada Kelompok Pelajar dan Mahasiswa Tahun 2016 (2016).
} 
Selain jual beli minuman beralkohol, masih banyak masyarakat yang mengkonsumsi narkoba, seperti yang diungkapkan oleh Komjen Pol Budi Waseso Kepala Badan Narkotika Nasional (BNN), ia mengatakan bahwa jumlah pengguna narkoba di Indonesia pada bulan Juni 2015 tercatat 4,2 juta dan pada bulan November 2015 meningkat signifikan hingga 5,9 juta, Ira Rachmawati, "buwas pengguna narkoba meningkat hingga 5,9 juta orang," kompas.com, 2016.. Hal ini menunjukan bahwa jika pengguna narkoba banyak maka berimplikasi pada maraknya transaksi jual beli narkoba. Dan ini merupakan bukti bahwa sebagian besar masyarakat Indonesia dalam melakukan transaksi jual beli tidak memperhatikan aspek halalan toyyiban. Padahal Allah mensyariatkan jual beli yang memiliki unsur halalan toyyiban

Fakta lain juga membuktikan bahwa masih banyak masyarakat dalam melakukan transaksi jual beli melakukan penipuan dengan memanipulasi takaran dan timbangan, yang terpenting bagi mereka adalah mendapatkan keuntungan yang sebesar-besarnya, artinya bukan ridha Allah yang mereka kehendaki tetapi uang yang melimpah yang mereka kehendaki. Seperti kasus yang terjadi pada pedangang sembako di Sentral Maros, yang melakukan kecurangan dalam menimbang terigu dengan menggunakan timbangan yang dibuatnya sendri bukan timbangan yang standar, artinya mereka melakukan manipulasi takaran dan timbangan pada pembeli. $^{2}$

Kasus-kasus tersebut sangatlah bertentangan dengan ajaran Islam yakni bertentangan dengan Al-Quran dan Al-Sunnah. Padahal, kita sebagai umat muslim haruslah memperhatikan jual beli yang halal dan baik (halalan thayyiban), baik dari segi objek barangnya (ma'qud alaih), dari segi orang yang berakadnya (ahliyah), dari segi akadnya (sighat) agar mendapatkan ridha Allah SWT. Ketidakpedulian masyarakat akan jual beli yang halal dan baik (halalan thayyiban) merupakan salah satu penyebab dari rendahnya pemahaman dan kesadaran masyarakat tentang konsep jual beli menurut Islam yang berdasarkan Al-Quran dan Al-Sunnah. Dengan dasar itulah peneliti ingin menganalisis bagaimana urgensitas penerapan prinsip halalan thayyiban pada aktivitas jual beli dalam pandangan ajaran Al-Quran dan AlSunnah.

\section{METODE}

\footnotetext{
${ }^{2}$ Akbar Musfira dan Asse Ambo, "Analisis Tingkat Kecurangan dalam Takaran dan Timbangan bagi Pedagang Terigu (Studi Kasus di Pasar Sentral Maros)," 2017.
} 
Jenis penelitian yang digunakan oleh peneliti adalah kualitatif dan metode penelitiannya adalah deskriptif, dengan cara memaparkan bagaimana konsep jual beli menurut islam dalam perspektif Al-Quran dan Al-Sunnah. Adapun teknik pengumpulan datanya adalah dengan menggunakan data sekunder yaitu dengan melakukan studi pustaka dari beberapa jurnal dan buku yang berkaitan dengan penelitian ini. Teknik pengumpulan data dilakukan dalam rangka mencari dan mengumpulkan data penelitian adalah dengan studi kepustakaan (library research), yang dilakukan dengan cara membaca, mempelajari, menelaah, memahami dan menganalisis serta menyusunnya dari berbagai literatur dan peraturanperaturan yang ada relevansinya dengan masalah yang diangkat dalam penelitian. Adapun analisis yang digunakan adalah deskriftif-kualitatif, yaitu analisis yang dilakukan dengan memaparkan data-data yang diperoleh dan kemudian menganalisa sehingga mendapatkan sebuah kesimpulan. Langkah-langkah dalam analisis data tersebut meliputi: (1) Menelaah semua data yang terkumpul dari berbagai sumber, baik primer atau sekunder; (2) Mengklasifikasi seluruh data ke dalam satuan-satuan permasalahan sesuai dengan perumusan masalah; (3) Manganalisis unsur-unsur dalil yang digunakan tentang masalah yang dibahas; (4) Menarik kesimpulan hasil analisis tentang masalah yang dibahas.

\section{HASIL DAN PEMBAHASAN}

\section{a. Tinjauan Teoritis tentang Jual Beli}

\section{1) Pengertian jual beli}

Jual beli menurut bahasa yaitu mutlaq al-mubadalah yang berarti tukar menukar secara mutlak. ${ }^{3}$ Atau dengan ungkapan lain yaitu muqabalah syai'bi syai' yaitu tukar menukar sesuatu dengan sesuatu ${ }^{4}$. Sedangkan Jual beli dalam istilah fiqh disebut dengan al-bai' yang berarti menjual, mengganti, dan menukar sesuatu dengan sesuatu yang lain. Lafal albai' dalam bahasa Arab terkadang digunakan untuk pengertian lawannya, yakni kata asy- syira yang berarati beli. Dengan demikian, kata al-bai' berarti jual, tetapi sekaligus juga berarti beli ${ }^{5}$.

Menurut ulama Hanafiyah jual beli menurut istilah adalah saling menukarkan harta dengan harta melalui cara tertentu, atau dengan makna tukar menukar sesuatu yang diingini dengan sepadan melalui cara tertentu yang bermanfaat. Ulama Hanafiyah menjelaskan bahwa makna khusus pada

\footnotetext{
${ }^{3}$ Sabiq Sayyid, fiqih sunnah, juz 3, 1983.

${ }^{4}$ Wahbah Zuhaily, al-Fiqh al-Islam wa Adillatuh, juz 4, 1984.

${ }^{5}$ Shobirin, “Jual Beli Dalam Pandangan islam," Jual Beli dalam Pandangan Islam 3 (2015): 2.
} 
pengertian pertama tadi adalah ijab dan kabul, atau juga bisa melalui saling memberikan barang dan menetapkan harga antara pembeli dan penjual. Sedangkan pada pengertian kedua menjelaskan bahwa harta yang diperjualbelikan itu harus bermanfaat bagi manusia, seperti menjual bangkai, minuman keras dan darah tidak dibenarkan ${ }^{6}$. Sedangkan menurut ulama malikiyah, syafi'iyah dan hanabilah jual beli adalah saling tukar menukar harta dengan harta dalam bentuk pemindahan milik dan pemilikan?.

Jual beli merupakan salah satu cara perpindahan kepemilikan yang dihalalkan oleh Al-Quran. Jual beli telah ada sebelum Al-Quran diturunkan. A-Quran mengatur tijarah (bisnis) yang pelaksanaannya dilakukan atas dasar saling rela ${ }^{8}$. Dalam hal ini, jual beli barang merupakan transaksi paling banyak dalam dunia perniagaan (bisnis). Asal jual beli adalah diperbolehkan, namun jika jual beli tersebut berbenturan dengan syariat islam maka jual beli tersebut diharamkan dan ada juga yang diperselisihkan hukumnya. Oleh sebab itu, Usahawan Muslim harus mengetahui hal-hal apa saja yang menentukan sah tidaknya jual beli tersebut, dan mengetahui mana yang halal dan mana yang haram dari kegiatan itu ${ }^{9}$.

\section{2) Rukun jual beli}

Rukun secara bahasa adalah yang harus dipenuhi untuk sahnya suatu pekerjaan. Dalam buku Muhammad Amin Suma dijelaskan: rukun dalam berasal dari kata bahasa Arab yakni rukn jamaknya arkan, secara harfiah berarti tiang, penopang dan sandaran, kekuatan, perkara besar, bagian, unsur dan elemen. Sedangkan rukun menurut istilah diartikan dengan sesuatu yang terbentuk atau menjadi eksis sesuatu yang lain dari keberadaannya, mengingat eksisnya sesuatu itu dengan rukun itu sendiri, bukan karena tegaknya. Kalau tidak demikian, maka subjek (pelaku) berarti menjadi unsur bagi pekerjaan, dan jasad menjadi rukun bagi sifat, dan yang disifati (almaushuf) menjadi unsur bagi sifat (yang mensifati) ${ }^{10}$. Rukun dan syarat merupakan salah satu syarat yang harus dipenuhi dalam melakukan transaksi jual beli agar transaksi jual belinya menjadi sah. Dalam menentukan rukun jual beli terdapat perbedaan pendapat antara ulama Hanafiyah dengan jumhur ulama.

\footnotetext{
${ }^{6}$ Syaifullah, “Etika Jual Beli Dalam Islam," Etika Jual Beli Dalam Islam 11 (2014): 2.

${ }^{7}$ Nurjannah dan Juju Jumena, "Praktek Jual Beli Kain Kiloan dalam Perspektif Hukum Islam," Al-Mustashfa 3, no. 2 (2016).

${ }^{8}$ Fhatoni Nur, "Konsep Jual Beli dalam Fatwa DSN-MUI," Konsep Jual Beli Dalam Fatwa DSNMUI IV (2013).

${ }^{9}$ Nurjannah dan Jumena, "Praktek Jual Beli Kain Kiloan dalam Perspektif Hukum Islam."

${ }^{10}$ Shobirin, "Jual Beli Dalam Pandangan islam."
} 
Menurut ulama hanafiyah yang menjadi rukun jual beli hanya satu, yaitu ijab qabul, ijab adalah ungkapan membeli dari pembeli, dan qabul adalah ungkapan menjual dari penjual. Menurut mereka, yang menjadi rukun dalam jual beli itu hanyalah kerelaan (ridha) kedua belah pihak untuk melakukan transaksi jual beli.Akan tetapi, karena unsur kerelaan itu merupakan unsur hati yang sulit untuk diindra sehingga tidak kelihatan, maka diperlukan indikasi yang menunjukkan kerelaan itu dari kedua belah pihak. Indikasi yang menunjukkan kerelaan kedua belah pihak yang melakukan transaksi jual beli menurut mereka boleh tergambar dalam ijab dan qabul, atau melalui cara saling memberikan barang dan harga barang. Menurut ulama Hanafiyah, orang yang berakad, barang yang dibeli, dan nilai tukar barang termasuk kedalam syarat-syarat jual beli, bukan rukun jual beli11. Berbeda dengan jumhur ulama, yang mengatakan bahwa rukun jual beli ada 4 (empat) yaitu:

a) Penjual (ba'i) dan pembeli (mustari)

b) Serah-terima (ijab qabul)

c) Barang atau objek yang diperjualbelikan ( $m a^{\prime}$ 'qud 'alaih $)^{12}$

d) Nilai tukar (harga barang) ${ }^{13}$

\section{3) Syarat-Syarat Jual Beli}

Syarat dalam bahasa Arab berarti syarth jamaknya syara'ith secara literal berarti pertanda, indikasi dan memastikan. Menurut Muhammad Khudlari Bek, syarat menurut istilah adalah sesuatu yang ketidakadaannya mengharuskan dan mengakibatkan tidak adanya hukum itu sendiri. Syarat adalah ketentuan (peraturan, petunjuk) yang harus diindahkan dan dilakukan. Hikmah dari ketiadaan syarat itu berakibat pula meniadakan hikmah hukum atau sebab hukum ${ }^{14}$. Definisi syarat berkaitan dengan sesuatu yang tergantung padanya keberadaan hukum syar'i dan ia berada di luar hukum itu sendiri, yang ketiadaannya menyebabkan hukum pun tidak ada. Perbedaan antara rukun dan syarat menurut ulama ushul fiqih, yaitu rukun merupakan sifat yang kepadanya tergantung keberadaan hukum dan termasuk dalam hukum itu sendiri, sedangkan syarat merupakan sifat yang kepadanya tergantung keberadaan hukum, tetapi ia berada di luar hukum itu sendiri. Misalnya, rukuk dan sujud adalah rukun shalat. la merupakan bagian dari shalat itu sendiri. Jika tidak ada rukuk dan sujud dalam shalat, maka shalat itu batal, tidak sah. Syarat shalat salah satunya adalah wudhu. Wudhu

\footnotetext{
${ }^{11}$ Nasrun Haroen, Fiqih Muamalah (jakarta: Gaya Media Pratama, 2007).

${ }^{12}$ Darmawati, "Perilaku Jual Beli di Kalangan Pedagang Kaki Lima dalam Perspektif Etika

Bisnis Islam," Fenomena IV, no. 2 (2012).

${ }^{13}$ Nasrun Haroen, Fiqih Muamalah.

${ }^{14}$ Shobirin, "Jual Beli Dalam Pandangan islam."
} 
merupakan bagian di luar shalat, tetapi dengan tidak adanya wudhu, shalat menjadi tidak sah ${ }^{15}$.

Ini berarti kalau diumpamakan dalam jual beli, misalnya penjual dan pembeli adalah rukun jual beli, ia merupakan bagian dari jual beli itu sendiri ${ }^{16}$. Jika tidak ada penjual dan pembeli maka jual beli tersebut batal atau tidak sah. Salah satu syarat jual beli adalah berakal sehat (mumayyiz). Mumayyiz merupakan bagian diluar jual beli, tapi dengan tidak terpenuhinya mumayyiz, maka jual beli tersebut tidak sah.

Menurut ulama Hanafiyah bahwa orang yang berakad, barang yang dibeli, dan niilai tukar barang termasuk kedalam syarat jual beli bukan rukun jual beli. Sedangkan menurut jumhur ulama bahwa syarat-syarat jual beli adalah sebagai berikut:

\section{Pertama, syarat-syarat bagi penjual dan pembeli (ba'i wa musytari)}

Para ulama figh sepakat bahwa orang yang melakukan akad jual beli itu harus memenuhi syarat, yaitu:

a) Berakal sehat (mumayyiz)

Mumayiz adalah dapat membedakan sesuatu yang baik atau buruk, sekitar umur tujuh tahun. jual beli tidak dipandang sah jika dilakukan oleh orang gila dan anak kecil yang belum berakal. Menurut ulama Hanafiyah, Malikiyah, Hanabilah berpendapat transaksi jual beli yang dilakukan oleh anak kecil yang telah mumayyiz adalah sah selama ada izin walinya., sedangkan menurut ulama syafi'iyah jual beli yang dilakukan oleh anak kecil tidak sah, karena tidak ada kepantasan atau kemapuan (ahliyah) dalam hal ini ulama Syafi'iyah memandang bahwa orang yang berakad (aqid) disyaratkan cerdas, maksudnya telah baligh, dan memiliki ahliyah dalam persoalan agama dan harta.

b) Atas kemauan sendiri

Jual beli dengan adanya paksaan dan intimidasi pihak ketiga maka tidak sah, karena salah satu prinsip jual beli adalah suka sama suka. Suka sama suka, yaitu kehendak sendiri dan tidak dipaksa pihak manapun. Ketiga, yang mkecuali pemaksaan itu mesti dilakukan karena menjaga hak orang lain, seperti menjual barang gadai karena keputusan hakim untuk melunasi hutangnya.

c) Bukan pemboros dan pailit

Orang ini tidak dibenarkan untuk melakukan jual beli karena mereka dikenakan hajru yaitu larangan bertransaksi terhadap harta. Bagi pemboros dilarang melakukan jual beli karena

\footnotetext{
${ }^{15}$ Shobirin.

${ }^{16}$ Nurjannah dan Jumena, "Praktek Jual Beli Kain Kiloan dalam Perspektif Hukum Islam."
} 
menjaga hartanya dari kesia-siaan, sedangkan bagi orang pailit dilarang melakukan jual beli karena menjaga hak orang lain ${ }^{17}$.

\section{Kedua, syarat-syarat ijab qabul}

Syarat-syarat ijab qabul adalah sebagai berikut:

a) Ijab dan qabul diucapkan oleh orang yang mampu Menurut ulama Hanafiyah orang yang mngucapkan ijab Orang yang mengucapkannya telah baligh dan berakal

b) Kabul harus berkesuaian dengan ijab Apabila antara ijab dan qabul tidak sesuai maka jual beli tidak sah

c) Menyatukan majelis atau tempat akad ljab dan qabul dilakukan dalam satu majelis. Maksudnya kedua belah pihak yang melakukan jual beli hadir dan membicarakan topik yang sama.

\section{Ketiga, syarat-syarat barang yang diperjualbelikan}

Menurut Rozalinda, syarat-syarat barang yang diperjualbelikan sebagai berikut:

a) Milik sendiri

Barang yang bukan milik sendiri tidak boleh diperjualbelikan kecuali ada mandat yang diberikan oleh pemilik seperti akad wakalah (perwakilan)

b) Benda yang diperjualbelikan harus jelas, sifat, ukuran dan jenisnya

Jual beli terhadap sesuatu yang belum berwujud atau tidak jelas wujudnya tidak sah. Seperti jual beli buah-buahan yang belum jelas buahnya, jual anak hewan yang masih ada di perut induknya, jual beli susu yang masih dalam susu induknya (belum diperas)

c) Benda yang diperjualbelikan dapat diserahterimakan ketika akad secara langsung maupun tidak langsung

Ini berarti tidak sah jual beli yang tidak dapat diserahterimakan, misalnya jual beli burung yang terbang di udara, dan ikan di lautan

d) Benda yang diperjualbelikan adalah mal mutaqawwin

Mal mutaqawwin adalah benda yang dibolehkan syariat untuk memanfaatkannya. Ini berate tidak sah jual beli benda yang tidak dibolehkan syariat untuk memanfaatkannya, seperti bangkai, babi, minuman keras dan lain-lain.

e) Benda yang diperjualbelikan harus suci

Tidak sah melakukan jual beli terhadaap najis dan benda-benda yang mengandung najis. Rozalinda.

\footnotetext{
${ }^{17}$ Rozalinda, Fiqih Ekonomi Syariah (Jakarta: Raja Grafindo Persada, 2015).
} 
Sedangkan menurut Wawan Djuaedi ${ }^{18}$, syarat-syarat yang terkait dengan barang yang diperjualbelikan sebagai berikut:

a) Barang yang diperjualbelikan jelas dan dapat dikuasai

b) Barang yang diperjualbelikan dapat diketahui kadarnya, jenisnya, sifat, dan harganya

c) Boleh diserahkan saat akad berlangsung .Suci, dalam islam tidak sah melakukan transaksi jual beli barang najis, seperti bangkai, babi, anjing, dan sebagainya

d) Barang yang diperjualbelikan merupakan milik sendiri atau diberi kuasa orang lain yang memilikinya

e) Barang yang diperjualbelikan ada manfaatnya. Contoh barang yang tidak bermanfaat adalah lalat, nyamuk, dan sebagainya. Barang-barang seperti ini tidak sah diperjualbelikan. Akan tetapi, jika dikemudian hari barang ini bermanfaat akibat perkembangan teknologi atau yang lainnya, maka barang-barang itu sah diperjualbelikan.

\section{Keempat, syarat-syarat nilai tukar (harga barang)}

Nilai tukar barang yang dijual (untuk zaman sekarang adalah uang), para ulama figh membedakan al-tsaman dengan al-si'r. Menurut mereka, altsaman adalah harga pasar yang berlaku di tengah-tengah masyarakat secara aktual, sedangkan al-si'r adalah modal barang yang seharusnya diterima para pedagang sebelum dijual ke konsumen (pemakai). Dengan demikian, harga barang itu ada dua, yaitu harga antara pedagang dan harga antara pedagang dan konsumen (harga dipasar) ${ }^{19}$.

Nilai tukar suatu barang merupakan salah satu unsur terpenting. Ulama fiqih memberikan penjelasan bahwa syarat nilai tukar adalah sebagai berikut:

a) Harga yang disepakati kedua belah pihak harus jelas jumlahnya.

b) Dapat diserahkan pada saat waktu transaksi, sekalipun secara hukum seperti pembayaran dengan cek atau kartu kredit. Apabila barang dibayar kemudian (berhutang), maka waktu pembayarannya harus jelas waktunya.

c) Jika jual beli itu dilakukan dengan cara barter, maka barang yang dijadikan nilai tukar, bukan barang yang diharamkan syara' seperti babi dan khamar ${ }^{20}$.

\footnotetext{
${ }^{18}$ Wawan Djuaedi, Fiqih (Jakarta: Lista Farista Putra, 2008).

${ }^{19}$ Ghufron Ihsan, Fiqh Muamalat (Jakarta: Prenada Media Grup, 2008).

${ }^{20}$ Syaifullah, "Etika Jual Beli Dalam Islam."
} 
Disamping syarat-syarat tersebut diatas, ulama fiqh juga mengemukakan beberapa syarat lain. Ulama fiqih menyatakan, bahwa suatu jual beli baru dianggap sah, bila terpenuhi dua hal:

a) Jual beli tersebut terhindar dari cacat. Baik dari segi barang yang diperjualbelikan tidak jelas, dan jual beli tersebut mengandung unsur paksaan dan penipuan sehingga mengakibatkan jual beli tersebut rusak.

b) Barang yang menjadi objek jual beli tersebut jika merupakan barang yang bergerak, maka barang tersebut dengan otomatis menjadi milik pembeli dan harga dari barang tersebut menjadi milik penjual. Namun jika barang yang menjadi objel jual beli merupakan barang yang tidak bergerak, maka barang tersebut boleh dikuasai setelah surat-menyuratnya sudah diselesaikan sesuai dengan ketentuan yang berlaku ditempat tersebut.

Selanjutnya, transaksi jual beli baru dapat dilaksanakan jika yang berakad mempunyai kekuasaan penuh dalam bertransaksi. Kekuasaan yang dimaksud di sini adalah bahwa orang yang berakad adalah punya wewenang penuh terhadap barang yang menjadi objek transaksi. Apabila kekuasaan tidak dimiliki oleh orang yang bertransaksi, maka jual beli tersebut tidak dapat dilakukan, dan jika proses transaksi terbebas dari segala macam khiyar, maka transaksi tersebut akan mengikat terhadap kedua belah pihak. Khiyar yang dimaksud di sini adalah hak pilih untuk meneruskan atau membatalkan jual beli. Jual beli yang masih mempunyai hak khiyar maka jual beli tersebut belum mengikat dan dapat dibatalkan. Jika semua syarat-syarat diatas terpenuhi, maka suatu proses jual beli telah dianggap sah, serta bagi kedua belah pihak tidak dapat lagi membatalkannya. Syaifullah.

Tujuan diadakannya syarat-syarat dalam jual beli, antara lain:

a) Untuk mencegah terjadinya perselisihan diantara manusia

b) Menjaga kemaslahatan pihak-pihak yang melakukan akad

c) Menghilangkan sifat gharar (penipuan) ${ }^{21}$.

\section{4) Macam-macam jual beli}

Macam-macam jual beli berdasarkan pertukarannya dibagi 4 (empat), yaitu22:

a) Jual beli salam (pesanan)

Jual beli salam yaitu jual beli melalui pesanan dengan cara menyerahkan uang terlebih dahulu dan barang kemudian.

\footnotetext{
${ }^{21}$ Makki Hali, "Persfektif Hukum Islam terhadap Hak Arisan di Desa Kropoh Sumenep," istidlal 1, no. 1 (2017).

${ }^{22}$ Syafe'i Rachmat, Fiqih Muamalah (Bandung: Pustaka Setia, 2000).
} 
Menurut al-Bahuti dalam Haris Faulidi, as-salam atau disebut juga as-salaf merupakan istilah dalam bahasa Arab yang mengandung makna penyerahan. ia mendefinisikan as-salam sebagai transaksi atas sesuatu yang masih berada dalam tanggungan dengan kriteria tertentu dan diserahkan kemudian dengan pembayaran harga di tempat kontrak. Atau ringkasnya disebutkan jual beli yang ditangguhkan dengan harga disegerakan ${ }^{23}$.

b) Jual beli muqayadhah (barter)

Jual beli dengan cara menukar barang dengan barang

c) Jual beli mutlaq

Jual beli barang dengan sesuatu yang telah disepakati sebagai alat tukar seperti uang

d) Jual beli alat penukar dengan alat penukar

Jual beli barang yang biasa dipakai sebagai alat penukar dengan alat penukar lainnya seperti uang emas dana uang perak

Macam-macam jual beli berdasarkan harga dibagi 4 (empat), yaitu:

a) Jual beli yang menguntungkan (murabahah)

b) Jual beli yang tidak menguntungkan, yaitu menjual dengan harga aslinya (tauliyah)

c) Jual beli rugi (khasarah)

d) Jual beli musawah, yaitu jual beli yang penjual menyembunyikan harga aslinya, tapi kedua orang yang berakad saling meridhai ${ }^{24}$.

Ditinjau dari hukum dan sifat jual beli, jumhur ulama membagi jual beli menjadi 2 (dua) macam, yaitu:

a) Jual beli shahih (sah),

Jual beli yang memenuhi ketentuan syara baik rukun maupun syaratnya

b) Jual beli ghair shahih (tidak sah atau batal)

Jual beli yang tidak memenuhi syarat atau rukun sehingga jual beli menjadi fasid atau batal. Menurut jumhur ulama fasid atau batal memiliki arti sama.

Sedangkan Ulama Hanafiyah membagi jual beli berdasarkan sah atau tidaknya jual beli menjadi 3(tiga) macam yaitu:

a) Jual beli shahih

\footnotetext{
${ }^{23}$ Muttaqin Azhar, "Transaksi E-Comerce dalam Tinjauan Hukum Jual Beli Islam," ulumuddin VII, no. 1 (2013).

${ }^{24}$ Syafe'i Rachmat, Fiqih Muamalah.
} 
Jual beli dikatakan shahih jika jual beli itu disyariatkan, memenuhi rukun dan syarat yang ditentukan, bukan milik orang lain dan tidak tergantung pada hak khiyar lagi.

b) Jual beli bathil

Jual beli dikatakan batal jika salah satu atau seluruh rukunnya tidak terpenuhi atau jual beli itu sifatnya tidak disyariatkan. Seperti jual beli yang dilakukan anak-anak, orang gila, atau barang yang diperjualbelikan itu barang yang diharamkan syara seperti bangkai, darah, babi, khamar.

c) Jual beli fasid

Ulama hanafiyah membedakan jual beli fasid dengan jual beli batal. Jika kerusakan dalam jual beli itu terkait barang yang diperjualbelikan maka hukumnya batal, seperti memperjualbelikan benda-benda haram, seperti khamar, bangkai, darah, babi. Namun jika kerusakan itu menyangkut pada harga barang dan boleh diperbaiki maka jual beli itu disebut fasid. Akan tetapi jumhur ulama tidak membedakan antara jual beli fasid dan batal. Menurut mereka jual beli itu terbagai dua yaitu jual beli shahih dan jual beli batal ${ }^{25}$.

Macam-macam Jual beli bathil, yaitu:

a) Jual beli $m a^{\prime} d u m$ (tidak ada bendanya)

Jual beli yang dilakukan terhadap sesuatu yang tidak atau belum ada ketika akad. Jual beli ini bathil sesuai hadits nabi yang artinya "Rosulullah melarang jual beli binatang yang masih dalam perutnya"

b) Jual beli sesuatu yang tidak dapat diserahterimakan Contohnya seperti jual beli burung yang sedang terbang di udara

c) Jual beli gharar

Jual beli yang mengandung tipuan. Jual beli gharar diantaranya: pertama, jual beli muzabanah, yaitu jual beli buah-buahan yang masih dalam pelapahnya. Kedua, jual beli mulamasah, yaitu jual beli dengan cara menyentuh barang. Jual beli munabazah, yaitu jual beli dengan melempar barang. Ketiga, jual beli thalaqi alruqban dan jual beli hadhir libad, yaitu jual beli dengan menghadang pedagang dari desa yang belum tahu harga pasaran. Keempat, jual beli al-najasy, yaitu jual beli yanag dilakukan dengan cara memuji barang atau menaikan harga (menawar)

\footnotetext{
${ }^{25}$ Makki Hali, “Persfektif Hukum Islam terhadap Hak Arisan di Desa Kropoh Sumenep.”
} 
harga tinggi dengan maksud hanya untuk mengelabui orang lain, tidak bermaksud untuk membeli atau menjualnya.

d) Jual beli najis dan benda-benda najis

Menurut ulama, seperti Hanafiyah, Malikiyah, Syafi'iyah, Hanabilah berpendapat tidak sah menlakukan jual beli khamar, babi, bangkai, darah, dan sperma karena semua itu menurut asalnya tidak dianggap sebagai harta.

e) Jual beli urbun (porsekot), yaitu jual beli yang dilakukan perjanjian pembeli menyerahkan uang seharga barang jika setuju jual beli dilaksanakan, tapi jika ia membatalkan jual beli maka uang yang telah dibayarkan menjadi hibah bagi penjual. Jumhur ulama berpendapat bahwa jual beli seperti ini tidak sah dan terlarang. Sedangkan ulama Hanafiyah mengatakan jual beli ini fasid.

f) Jual beli air, tidak sah melakukan jual terhadap barang yang dimiliki bersama oleh manusia, sepeti udara, air, tanah. Seluruh benda, seperti air laut, sumur umum, tidak boleh diperjualbelikan karena termasul mal mubah. Lain halnya dengan mal mubah yang telah dilakukan ihraz al-mubahat atau isti'la 'ala al-mubahat (penguasaan terhadap benda mubah) seperti menangkap ikan di laut, mengumpulkan kayu di hutan, menyuling air untuk air minum. Rozalinda, Fiqih Ekonomi Syariah.

Macam-macam jual beli fasid, yaitu:

a) Jual beli majhul, yaitu jual beli yang tidak jelas barang yang diperjualbelikan

b) Jual beli yang digantungkan kepada syarat dan digantungkan ke masa yang akan datang. Jumhur ulama mengatakan jual beli ini bathil sedangkan ulama Hanafiyah mengatakan bahwa jual beli ini fasid, karena ada syarat yang tidak terpenuhi

c) Jual beli yang ghaib atau tidak terlihat ketika akad

Menurut ulama Malikiyah, Hanafiyah, Hanabilah bahwa jual beli oleh orang buta sah asalkan ada hak khiyar. Sementara menurut ulama Syafi'iyah tidak sah jual beli orang buta kecuali ia melihat sebelum buta

d) Menjual dengan pembayaran yang ditunda dan membeli dengan harga tunai

Menurut ulama Syafi'iyah dan Zahiriyah jual beli ini sah karena terpenuhinya rukun dan syarat. Sedangkan ulama Malikiyah dan hanabilah jual beli ini bathil, semantara itu menurut Abu Hanifah jual beli ini fasid sebab dipandang sebagai hilah dari riba. 
e) Jual beli anggur dengan tujuan membuat khamar atau pedang dengan tujuan membunuh

Menurut Abu Hanifah dan Syafi'iyah jual beli ini zahirnya sah. Namun menjadi makruh karena anggur dijadikan khamar ulama Malikiyah dan Hanabilah bahwa jual beli ini bathil

f) Melakukan dua akad jual beli dalam satu akad atau dua syarat dalam satu akad

Misalnya, seseorang berkata"Saya jual rumah saya kepadamu kemudian kamu jual kudamu kepada saya" atau dengan ungkapan lain: "Saya beli barang ini, seribu saya bayar tunai dan seribu lagi saya bayar tangguh". Menurut Syafi'iyah jual beli ini bathil, sedangkan menurut ulama Hanafiyah jual beli ini fasid. Rozalinda.

\section{5) Jual Beli Yang Dilarang dalam Islam}

Dalam islam pada hakikatnya asal dari hukum jual beli itu adalah boleh. Hal ini sesuai dengan kaidah fiqih muamalah yang menyatakan bahwa asal dari bermuamalah adalah boleh kecuali ada dalil yang mengharamkannya. Dan juga diperkuat dalam kaidah ushuliyah bahwa asal dari larangan itu adalah haram. Ada beberapa jual beli yang dilarang dalam islam, yaitu:

\section{Pertama, terlarang sebab ahliah (ahli akad)}

Jual beli yang termasuk jual beli yang terlarang sebab ahliah, antara lain:

a) Jual beli oleh orang gila (termasuk orang mabuk)

b) Jual beli oleh anak kecil (belum mumayyiz)

Ulama fiqih sepakat jual beli ini tidak sah kecuali dalam perkara yang ringan. Menurut ulama Syafi'iyah jual beli oleh anak mumayyiz yang belum balig tidak sah sebab tidak ada ahliah. Menurut ulama Malikiyah dan Hanafiyah jual beli ini dipandang sah jika diizinkan walinya, alasanya melatih kedewasaan.

c) Jual beli oleh orang buta

Menurut jumhur ulama jual beli oleh orang buta dianggap shahih jika barang yang dibeli diterangkan sifatnya. Sedangkan menurut ulama Syafi'iyah jual beli oleh orang buta tiak sah sebab tidak dapat membedakan mana yang baik ataupun yang buruk.

d) Jual beli terpaksa

Menurut ulama Hanafiyah hukum jual beli ini ditangguhkan (mauquf), menurut ulama Malikiyah tidak lazim, baginya ada 
khiyar. Menurut ulama Syafi'iyah dan Hanabilah tidak sah karena tidak adanya keridhaan.

e) Jual beli fudhul

Jual beli milik orang tanpa seizin pemiliknya, menurut ulama Malikiyah dan Hanafiyah jual beli ini ditangguhkan sampa ada izin pemilik sedangkan menurut ulama Syafi' iyah dan Hanabilah tidak sah.

f) Jual beli orang yang terhalang

Jual beli orang yang terhalang, yang dimaksudkan adalah kebodohan, sakit, pailit. Menurut ulama Malikiyah dan Hanafiyah, Hanabilah jual beli ini digguhkan. Sedangkan menurut ulama Syafi'iyah, jual beli ini tidak sah sebab tidak ada ahlidan ucapan yang dapat dipegang

g) Jual beli malja'

Jual beli orang yang sedang dalam bahaya, yakni untuk menghindari dari perbuatan zalim. Jualbeli ini menurut Hanafiyah fasid sedangkan menurut hanabilah bathil. Syafe'i Rachmat, Fiqih Muamalah.

\section{Kedua, terlarang sebab shighat}

Jual beli yang termasuk jual beli yang terlarang sebab Sighat, antara lain:

a) Jual beli mu'athah

Jual beli yang disepakati oleh pihak yang berakad berkenaan dengan barang maupun harganya, tapi tidak memakai ijab qabul. Berkenaan dengan hal ini ulama hanafiah berpendapat bahwa jual belinya tidak sah, sedangkan menurut ulama syafi'iyah kecuali imam nawawi bahwa jual beli tersebut tidak sah kecuali dengan mengucapkan sighat ijab qabul tidak cukup dengan isyarat saja, adapun menurut jumhur ulama jual beli tersebut sahih jika ada ijab dari salah satu pihak dan diperbolehkan ijab qabul dengan isyarat, perbuatan atau cara lain yang menunjukan keridhaan, begitupun Ibnu Suraij dan Ar-Ruyani membolehkannya dalam hal-hal kecil

b) Jual beli melalui surat atau utusan

Ulama fiqih berpendapat, jual beli ini tidak sah jika qabul melebihi tempat, artinya jika surat tersebut tidak sampai ke tangan yang dimaksud. Namun jika sampainya atau utusan dari aqid pertama kepada aqid kedua, maka jual beli tersebut sah.

c) Jual beli dengan isyarat atau tulisan 
Jika isyarat tidak dapat difahami dan tulisannya jelek artinya tidak dapat dibaca, maka akad jual belinya tidak sah. Namun hal tersebut disepakati kesahihannya khusus bagi yang uzur sebab isyarat ataupun tulisan sama dengan ucapan, asalkan isyarat atau tulisannya dapat dipahami

d) Jual beli barang yang tidak ada di tempat akad

Ulama fiqih sepakat bahwa jual beli atas barang yang tidak ada di tempat akad adalah tidak sah sebab tidak memenuhi syarat in'iqad (terjadinya akad)

e) Jual beli yang tidak bersesuaian antara ijab dan qabul

Menurut jumhur ulama jual beli seperti ini tidak sah, sedangakan ulama Hanafiyah membolehkannya

f) Jual beli munjiz

Jual beli yang dikaitkan syarat atau ditangguhkan pada waktu yang akan dating. Jual blei ini dipandang fasid menurut ulama Hanafiyah dan batal menurut jumhur ulama

\section{Ketiga, terlarang sebab ma'qud alaih (barang jualan)}

Jual beli yang termasuk jual beli yang terlarang sebab ma'qud alaih antara lain:

a) Jual beli benda yang tidak ada atau dikhawatirkan tidak ada Jumhur ulama sepakat bahwa jual beli barang yang tidak ada atau dikhawatirkan tidak ada adalah tidak sah

b) Jual beli barang yang tidak dapat diserahkan Jual beli yang tidak dapat diserahkan seperti burung yang terbang di udara, ikan yang ada di air tidak sah

c) Jual beli gharar

Jual beli gharar adalah jual beli yang mengandung kesamaran. Menurut Ibnu Jazi Al-Maliki, Gharar yang dilarang adal 10 (sepuluh) macam, yaitu: jual beli yang tidak dapat diserakan (seperti hewan yang masih dalam kandungan), tidak diketahui harga dan barangnya, tidak diketahui sifat barang atau harganya, tidak diketahui ukuran harga dan barangnya, tidak diketahui masa yang akan dating (seperti saya mobil ini padamu jika jaed datang), menghargakan dua kali pada satu barang, menjual barang yang diharapkan selamat, jual beli husha (seperti pembeli memegang tongkat, jika tongkatnya jatuh maka wajib membeli), jual beli munabazah (dengan cara melempar), jual beli mulamasah (dengan cara mengusap)

d) Jual beli barang yang najis dan yang terkena najis 
jumhur ulama sepakat tentang larangan jual beli barang najis seperti khamar. Tapi mereka beda pendapat tentang barang yang terkena najis. Seperti minyak yang terkena bangkai tikus, ulama Hanafiyah membolehkan jika barang tidak untuk dimakan, sedangkan ulama Malikiyah membolehkan jika telah dibersihkan

e) Jual beli air

Ulama Zahiriyyah melarang jual beli air secara mutlak. Sedangkan menurut jumhur ulama, jual beli air yang dimiliki seperti air sumur milik sendiri diperbolehkan, sedangkan jual beli air yang mubah (dimanfaatkan oleh masyarakat) dilarang

f) Jual beli barang yang tidak jelas (majhul)

Menurut ulama Hanafiyah, jual beli seperti ini fasid sedangkan menurut jumhur ulama batal sebab akan menimbulkan pertentangan antara manusia

g) Jual beli barang yang tidak ada di tempat akad (ghaib), tidak dapat dilihat

Menurut ulama Syafi'iyah dan Hanabilah jual beli ini tidak sah, sedangkan menurut ulama Hanafiyah jual beli ini diperbolehkan tanpa harus menyebutkan sifat-sifatnya, tapi pembeli berhak khiyar, dan ulama Malikiyah juga membolehkan dengan menyebutkan sifat-sifatnya dan syaratnya adalah harus jauh sekali tempatnya, tidak boleh dekat sekali tempatnya, bukan pemiliknya harus memberikan gambaran, harus meringkas sifat barang secara menyeluruh, penjual tidak boleh memberikan syarat

h) Jual beli sesuatu sebelum dipegang

Ulama Syafi'iyah melarang jual beli ini secara mutlak, sedangkan ulama Hanafiyah melarang jual beli barang yang dapat dipindahkan sebelum dipegang, tapi untuk barang tetap diperbolehkan dan melarang jual beli atas makanan, sedangkan ulama Hanabilah melarang atas makanan yang diukur

i) Jual beli buah-buahan atau tumbuhan

Menurut jumhur ulama bahwa jual beli buah-buahan tapi belum matang maka batal sedangkan menurut ulama Hanafiyah akadnya fasid, namun jika buahnya telah amtang maak diperbolehkan, sedangakan jika tidak ada buah maka disepakatai tidak ada akad.Syafe'i Rachmat.

\section{Keempat, terlarang sebab syara'}

Jual beli yang termasuk jual beli yang terlarang sebab Syara, antara lain: 
a) Jual beli riba

Riba nasiah dan riba fadh/ adalah fasid menurut ulama Hanafiyah dan batal menurut jumhur ulama.

b) Jual beli dengan uang dari barang yang diharamkan

Menurut jumhur ulama jual beli seperti ini adalah batal, sebab menurut hadits Bukhari Muslim bahwa Rasulullah mengharamkan jual beli khamar, bangkai, anjing dan patung, sedangkan menurut ulama Hanafiyah jual beli ini fasid dan terjadi akad atas nilainya.

c) Jual beli barang dari hasil pencegatan barang

Jual beli dengan cara mencegat pedangan dalam perjalanan agar mendapat keuntungan. Ulama Hanafiyah berpendapat bahwa jual beli seperti ini makruh tahrim, sedangkan menurut ulama Safi'iyah dan Hanabilah pembeli boleh khiyar, menurut ulama malikiyah jual beli tersebut fasid

d) Jual beli waktu azan jumat

Menurut ulama Hanafiyah pada waktu azan pertama laki-laki berkewajiban melakukan shalat jumat, sedangakn menurut ulama lainnya, azan ketika khatib sudah ada di mibar. Ulama Hanafiyah berpendapat bahwa jual beli seperti ini makruh tahrim, sedangkan menurut ulama Safi'iyah jual beli ini shahih haram, menurut ulama malikiyah jual beli ini tidak jadi, menurut ulama Hanabilah jual beli ini tidah sah

e) Jual beli anggur untuk dijadikan khamar

Menurut ulama Hanafiyah dan Syafi'iyah zahirnya shahih tapi makruh, sedangkan ulama Malikiyan dan Hanabilah jual beli ini batal

f) Jual beli induk tanpa anaknya yang masih kecil

Jual beli ini dilarang, sampai anaknya besar dan mandiri

g) Jual beli barang yang sedang dibeli orang lain

Contohnya seperti seseotang sepakat membeli barang, namun dalam masa khiyar, lalau datang orang lain yang menyuruh untuk membatalkan sebab ia akan membelinya dengan harga yang lebih tinggi

h) Jual beli dengan memakai syarat

Menurut ulama Hanabilah jual beli ini tidak diperbolehkan jika hanya bermanfaat bagi salah satu yang akad, sedangkan menurut ulama Hanafiyaah jual beli seperti ini sah, jika syaratnya baik (seperti saya akan membeli baju ini jika bagain yang rusak dijahit 
dulu) begitupun ulama Malikiyah membolehkan jika bermanfaat. Syafe'i Rachmat.

\section{b. Konsep Halal dan Baik (Halalan Thayyiban)}

Kata halal (حالل) adalah istilah bahasa Arab berarti diizinkan" atau "boleh". Secara etimologi, halal berarti hal-hal yang boleh dan dapat dilakukan karena bebas atau tidak terikat dengan ketentuan yang melarangnya ${ }^{26}$. Halal menurut bahasa berarti membebaskan, melepaskan, memecahkan dan membolehkan. Halal menurut istilah dalam kaitan dengan hukum syara', ia memiliki dua pengertian. Pengertian pertama menunjukkan bahwa kata halal menyangkut kebolehan menggunakan benda-benda atau apa saja untuk memenuhi kebutuhan fisik, termasuk di dalamnya makanan, minuman, obat-obatan. Pengertian kedua berkaitan dengan kebolehan memanfaatkan, memakan, meminum, dan mengerjakan sesuatu yang kesemuanya ditentukan berdasarkan nash. Syafe'i Rachmat.. Qardhawi mengartikan halal sebagai segala sesuatu yang tidak mengandung zat-zat yang membahayakan dan diperbolehkan oleh Allah SWT. Menurut MUI yang dimaksud dengan produk halal adalah produk yang memenuhi beberapa kriteria sebagai berikut: pertama, tidak mengandung babi dan bahan yang berasal dari babi, kedua tidak mengandung bahan-bahan yang diharamkan, antara lain bahan yang diambil dari organ manusia, kotoran, dan darah, ketiga semua hewan halal yang disembelih sesuai dengan tuntunan syariat Islam, keempat seluruh penyimpanan, penjualan, pengolahan, pengelolaan dan transportasi bahan tersebut bukan bekas dipakai untuk babi, kecuali setelah dibersihkan dengan tata cara syariat Islam, kelima semua makanan dan minuman yang tidak mengandung khamar ${ }^{27}$.

Makna thayyib menurut keterangan Syeh Ar-Raghib al-Isfahani dalam Mu'jam Mufradat li Alfadhil Qur'an menyebutkan bahwa thayyib secara istilah adalah sesuatu yang dirasakan enak oleh indra dan jiwa. Kata ini merupakan derivasi dari kata thaba-yathibu-thayyiban yang secara bahasa maknanya adalah suci dan bersih, baik dan elok, serta enak. Dalam konteks fiqih thayyib diartikan halal juga. dalam al-Qur-an kata thayyib banyak disebutkan salah satunya dalam surat al-Baqarah ayat 168. Makna baik dari kata thayyib masih diperdebatkan oleh para ulama. Mereka memperdebatkan apa kriteria sesuatu barang dipandang baik. Dalam hal ini beberapa ulama berbeda pendapat

\footnotetext{
${ }^{26}$ Widyaningrum dan Premi Wahyu, "Pengaruh Label Halal dan Celebrity Endorser terhadap Keputusan Pembelian," Ekonomi Syariah Indonesia VI, no. 12 (2016).

${ }^{27}$ Sudirman dan Dahlan Tamrin, "Urgensi Labelisasi Halal di Tingkat Lokal," El-Qudwah, 2012.
} 
khususnya ulama ahli tafsir. Beberapa tafsir menyatakan dari perspektif kebahasan, bahwa kata thayyib adalah halal itu sendiri. Jadi keharusan mengkonsumsi makanan atau barang halal itu dikuatkan lagi dengan kata thayyiban setelahnya. Imam Ibnu Jarir ath-Thabari menyebutkan dalam karyanya Jami' Al Bayan fi Ta'wil Ay al Qur'an maksud dari kata thayyiban adalah suci, tidak najis, dan tidak haram. Ibnu Katsir berpenfdapat mengenai halalan thayyiban dalam surat al-Baqarah dalam tafsir al-Qur'an al-'Adhim adalah sesuatu yang baik, tidak membahayakan tubuh dan pikiran. Sedangkan al-Qurtubi dalam tafsirnya al-Jami' li Ahkam Qur'an menjelaskan kata halalan merupakan objek (maf'ul) dan kata thayyiban meupakan penjelas (hal) dari objel itu. Jadi status halal diperlukan karena ia inhilal (membebaskan) dari larangan yang ada untuk mengkonsumsi sesuatu. Kemudian kata thayyib meruju pada imam Syafi'i yakni sesuatu yang lezat dan layak untuk dikonsumsi ${ }^{28}$.

Menurut Burhanuddin jika barang tersebut pernah digunakan untuk babi atau barang yang tidak halal lainnya terlebih dahulu harus dibersihkan dengan tata cara yang diatur menurut syariat Islam. Selain itu juga semua makanan dan minuman dipastikan tidak mengandung khamar ${ }^{29}$. Produk halal menurut Islam memiliki syarat-syarat antara lain halal zatnya, halal cara memperolehnya, halal dalam prosesnya, halal dalam penyimpanannya, dalam pengangkutannya dan halal dalam penyajiannya. Produk kosmetik memang tidak dimakan dan masuk ke dalam tubuh. Oleh karena itu kosmetik biasanya dikaitkan dengan masalah suci atau najis. Produk tersebut bisa dikatakan haram jika produk kosmetik tersebut mengandung bahan-bahan najis, seperti turunan hewan (kolagen) ataupun bagian dari tubuh manusia, misalnya plasenta. Kosmetik halal juga tidak boleh mengandung alkohol, karena alkohol/Khamer tidak diperbolehkan dalam kehalalan suatu produk yang dikonsumsi ${ }^{30}$.

Dalam mempertahankan hidup seseorang diberi keleluasaan dalam mengambil sikap guna memenuhi kebutuhan-kebutuhanya, dengan cara mengkonsumsi barang yang dibutuhkan, namun harus sesuai dengan syariat Islam ${ }^{31}$. Cara masyarakat bagaimana memilih barang yang dikonsumsinya salah satunya dengan melihat kemasan apakah produk tersebut mencantumkan label hal MUI atau tidak. Label halal merupakan

\footnotetext{
${ }^{28}$ Syafe'i Rachmat, Fiqih Muamalah.

${ }^{29}$ Widyaningrum dan Wahyu, "Pengaruh Label Halal dan Celebrity Endorser terhadap Keputusan Pembelian."

${ }^{30}$ Widyaningrum dan Wahyu.

${ }^{31}$ Hendiana Runto dan Ahmad dasuki Ali, "Transaksi Jual Beli Online dalam Perspektif Hukum Islam," Al-mushtasfha 3, no. 2 (2016).
} 
pencantuman tulisan atau pernyataan halal pada kemasan produk untuk menunjukkan bahwa produk yang dimaksud berstatus sebagai produk halal. Label halal diperoleh setelah mendapatkan sertifikat halal. Menurut Petunjuk teknis system produksi halal yang diterbitkan oleh Departemen Agama Sertifikat halal adalah suatu fatwa tertulis dari Majelis Ulama Indonesia (MUI) yang menyatakan kehalalan suatu produk sesuai dengan syariat Islam. Sertifikat halal ini merupakan syarat untuk mendapatkan ijin pencantuman label halal pada kemasan produk dari instansi pemerintah yang berwenang. Adapun yang dimaksud dengan produk halal adalah produk yang memenuhi syarat kehalalan sesuai dengan syariat Islam ${ }^{32}$.

Penanganan sertifikasi halal di Indonesia selama ini dilakukan oleh Lembaga Pengkajian dan Penelitian Obat-obatan dan makanan (LPPOM) MUI, sebuah lembaga swadaya masyarakat yang merupakan wadah ulama Indonesia dari berbagai unsur Islam yang ada di Indonesia. Namun dengan keluarnya Undang-undang Nomor 33 Tahun 2014 tentang Jaminan Produk halal, sertifikasi halal menjadi wewenang Badan Penyelenggara Jaminan Produk halal (BPJPH) yang merupakan lembaga negara. Artinya terjadi pergeseran dari gerakan civil society ke program negara ${ }^{33}$.

Kehalalan sangat penting untuk diperhatikan, sebab setiap makanan yang dikonsumsi dan masuk kedalam tubuh sangat mempengaruhi hubungan manusia dengan Tuhannya (hablum minallah). Makanan yang haram akan menjadi penghalang diterimanya ibadah dan dikabulkannya do'a ${ }^{34}$. Kehalalan merupakan jaminan ketenangan bathin seorang muslim dalam konsumsi barang. Kehalalan dapat dipandang sebagai sebagai jaminan keamanan ruhani, sehingga untuk kebutuhan jasmani tetap harus memperhatikan keamanan dan kesehatan (hygiene) barang (seperti makanan dan minuman) yang dikonsumsi. Keamanan merupakan jaminan bahwa barang yang dikonsumsi terbebas dari bahan-bahan beracun, bibit penyakit, atau bahan-bahan lain yang membahayakan tubuh. Makanan yang sehat adalah makanan yang mengandung banyak nutrisi. Dengan memperhatikan kehalalan dan keamanan pangan, maka seorang muslim akan menjadi individu yang sehat ruhani dan jasmaninya, sehingga mampu berperan dengan baik sebagai hamba Tuhan maupun sebagai khalifah-Nya di bumi. Kata rijs mengandung arti "keburukan budi pekerti dan kebobrokan moral". Sehingga apabila Al-Qur'an menyebut makanan tertentu dan menilainya dengan rijs maka

\footnotetext{
${ }^{32}$ Widyaningrum dan Wahyu, "Pengaruh Label Halal dan Celebrity Endorser terhadap Keputusan Pembelian."

${ }_{33}$ Zumar Muhammad, "Sertifikat Halal Studi Perbandingan Indonesia dengan Thailand," Shahih: Journal of Islamicate Multidisciplinary 1, no. 1 (2016).

${ }^{34}$ Lahaling Hijrah, Makkulawuzar Kindom, dan Rukka Singkeru, "Labelisasi Haram terhadap Perlindungan Konsumen," Hasanuddin Law Review 1, no. 2 (2015).
} 
makanan tersebut dapat menimbulkan efek negatif terhadap budi pekerti dan moral yang mengkonsumsinya ${ }^{35}$.

Selain makanan atau minuman itu harus halal juga harus baik (thoyyib, hal ini berkaitan dengan pola konsumsi manusia, agar selalu memperhatikan makanan yang mangandung gizi, yang dapat mendukung kesehatan dan kelangsungan hidup. Di samping kehalalan dan sifat baik dari makanan masih ada lagi persyaratan yang lain yang cukup penting dalam mengkonsumsi makanan. Persyaratan adalah sebagai usaha yang dilakukan dalam memperoleh dan membuatnya. Rezeki yang diperoleh dengan cara yang haram seperti pangan, sandang, tempat tinggal, sebagian ulama ada yang berpendapat hasilnya haram untuk dikonsumsi meskipun makanan tersebut makanan yang halal, agar hal tersebut dapat terealisasikan maka harus selain dari yang disebutkan diatas maka harus ada kesadaran dari masyarakat itu sendiri. Kesadaran itu muncul tidak dengan sendirinya, akan tetapi ada faktor yang melatarbelakngi. Bagi Poerwadarminto kesadaran seseorang tentu berasal dari pengetahuan hukum yang berlaku, sementara menurut Widjaja kesadaran seseorang muncul karena dia memahami hakekat dirinya sendiri dan pada pandangan lqbal kesadaran tumbuh karena pemahaman religius seseorang. Adapun hakekat kesadaran dalam Islam adalah mengenal Allah dan selalu mengingat-Nya serta sadar akan kedudukan dirinya sebagai hamba Allah dan juga khalifah di muka bumi sehingga tidak terjerumus untuk berbuat kefasikan (melanggar larangan Tuhan) yang diwujudkan dengan melaksanakan perintah-Nya dan menjauhi larangan-Nya sebagai wujud penghambaan terhadap-Nya ${ }^{36}$.

\section{c. Dasar Hukum Jual Beli dan Halalan Thayyiban}

1) Dasar Hukum Jual Beli

\section{a) Jual beli persfektif Al-Quran}

Pertama, dasar hukum jual beli dapat dilihat dalam Al-Quran surat AlNisa ayat $29^{37}$, bahwasanya Allah SWT melarang jual beli dengan cara bathil ${ }^{38}$

\footnotetext{
${ }^{35}$ Al-Wasim Arif, "Label Halal dan Hukum Asal Bahan Pangan," Studi Al-Quran dan Hukum 2, no. 2 (2017): 311-26.

${ }^{36}$ Waluyo, "Pengaruh Pemahaman Agama, Motivasi Mendapatkan Profit,Tingkat Pendidikan terhadap Kesadaran Sertifikat Halal bagi Produsen di Kabupaten Sleman Bantul," Inferensi VII, no. 1 (2013): 75-98.

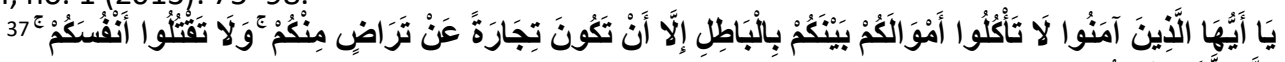

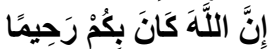
${ }^{38}$ santosa dkk., "Larangan Jual Beli Gharar ; Telaah dari Musnad Ahmad bin Hanbal," Ekonomi Syariah 3, no. 1 (2015): 157-73.
} 
menurut tafsir Jalalain ayat tersebut menjelaskan larangan kepada manusia, bahwa tidak diperbolehkan memakan harta sesamamu dengan cara bathil, maksud dari bathil disini adalah yang dilarang oleh syara seperti dengan jalan riba, ghasab, penipuan. Kecuali dengan jalan perniagaan yang didasari atas suka sama suka,artinya tanpa adanya paksaan berdasarkan kerelaan hati masing-masing, dan juga Allah melarang kepada manusia membunuh dirinya sendiri, maksudnya adalah tidak boleh mencelakakan dirinya sendiri atas perbuatan yang mereka lakukan yang telah dilarang oleh syara, seperti mereka tahu bahwa jual beli riba atau jual beli gharar itu tidak diperbolehkan oleh syara tapi mereka tidak menghiraukannya, dan tetap melakukannya, yang pada akhirnya dapat merugikan mereka sendiri baik di dunia maupun di akhirat. Selain itu, adanya larangan tersebut adalah bukti bahwa Allah sangat menyayangi hamba-Nya, agar tidak terjerumus kedalam jurang kemaksiatan ${ }^{39}$.

Sedangkan surat Al-Nisa ayat 29 menurut tafsir Ibnu Katsir, bahwa Allah SWT melarang hamba- hamba-Nya yang beriman memakan harta sebagian mereka terhadap sebagian lainnya dengan bathil, yaitu dengan berbagai macam usaha yang tidak syar'i seperti riba, judi dan berbagai hal serupa yang penuh tipu daya, sekalipun pada lahiriahnya cara-cara tersebut berdasarkan keumuman hukum syar'i, tetapi diketahui oleh Allah dengan jelas bahwa pelakunya hendak melakukan tipu muslihat terhadap riba ${ }^{40}$.

Kedua, selain surat Al-Nisa ayat 29, dasar hukum jual beli juga ada dalam surat Al-Baqarah ayat $275^{41}$, menurut tafsir Ibnu Katsir ayat tersebut menjelaskan bahwa orang yang memakan (mengambil) harta riba tidak dapat berdiri sendiri melainkan seperti berdirinya orang yang kemasukan syaitan lantaran tekanan penyakit gila, maksudnya adalah mereka tidak dapat berdiri dari kuburan mereka pada hari kiamat kelak kecuali seperti berdirinya orang gila pada saat mengamuk dan kerasukan syaitan, yaitu mereka berdiri dengan posisi yang tidak sewajarnya, disebabkan mereka berkata atau berpendapat bahwasanya jual beli itu sama dengan riba, dimana mereka membolehkan riba dengan maksud untuk menentang hukum-hukum Allah SWT yang terdapat dalam syariat-Nya ${ }^{42}$.

\footnotetext{
${ }^{39}$ Imam Jalaludin As-Suyuti dan Imam Jalaludin Al-Mahalli, Tafsir Jalalain (Bandung: Sinar Baru Algensindo, 2003).

${ }^{40}$ M. Abdul Ghoffar, Tafsir lbnu Katsir Jilid 2 (Bogor: Pustaka Imam Asy-Syafi'i, 2004).

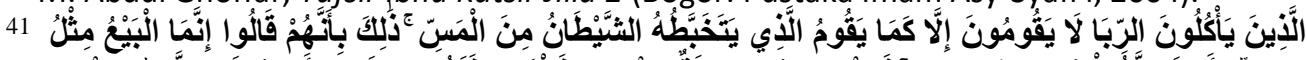

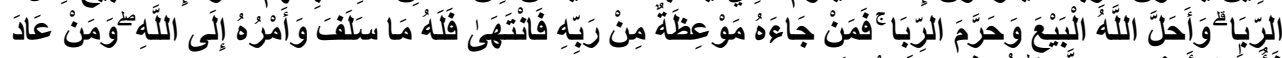

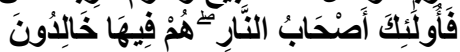

${ }^{42}$ Ghoffar, Tafsir Ibnu Katsir Jilid 2. 
Dalam hal ini mereka tidak mengqiyaskan riba dengan jual beli, sebab orang-orang musyrik tidak pernah mengakui penetapan jual beli yang telah ditetapkan Allah SWT di dalam al-Qur'an. Seandainya hal itu termasuk masalah qiyas, niscaya mereka akan mengatakan bahwa sesungguhnya riba itu sama seperti jual beli. Tetapi dalam hal ini mereka mengatakan bahwa jual beli itu sama dengan riba, yang demikian itu merupakan penentangan mereka terhadap syariat, artinya, yang ini sama dengan ini, dan Dia sendiri telah menghalalkan ini dan mengharamkan yang ini. Padahal Allah SWT telah menghalalkan jual beli dan mengharamkan riba ${ }^{43}$.

Adapun orang-orang yang telah sampai kepadanya larangan dari Rabbnya, lalu terus berhenti dari mengambil riba, maka baginya apa yang telah diambilnya dahulu (sebelum datangnya larangan), dan urusannya terserah kepada Allah, maksudnya adalah barangsiapa yang telah sampai kepadanya larangan memakan riba, lalu ia mengakhirinya ketika syariat sampai kepadanya, maka baginya hasil muamalah terdahulu. Sedangkan bagi orang yang mengulangi (mengambil riba), maksudnya adalah kembali mengambil riba, dan ia mengerjakannya setelah sampai kepadanya larangan tersebut, maka wajib baginya hukuman dan penegasan hujjah atasnya ${ }^{44}$.

Ketiga, dalam surat Al-Muthaffifin ayat 1-7 dijelaskan bahwa ajaran Islam mengajarkan manusia untuk melakukan transaksi jual beli secara adil tidak berbuat curang atau menipu. Sesuai dengan takaran yang sebenarnya, karena orang yang melakukan kecurangan dalam transaksi jual beli akan mendapatkan ganjaran pada hari dimana manusia akan dibangkitkan. Selain itu juga, mengambil hak orang lain sangat dilarang dalam agama Islam, sehingga orang yang mengurangkan takaran atau timbangan sedikitpun, akan masuk neraka, apalagi mengambilnya lebih banyak dari pada itu. Maka tentu akan lebih besar siksaannya. Oleh sebab itu patut kita insaf dan berhati-hati tentang hak orang itu, sebab dosanya tidak akan diampuni oleh Allah, sebelum dibayar haknya atau dimaafkannya. Tetapi dosa terhadap kepada Allah saja, seperti meninggalkan shalat maka Allah akan mengampuninya dengan semata-mata taubat kepadanya ${ }^{45}$.

\section{b) Jual Beli Perspektif Al-Sunnah}

Pertama, dasar hukum jual beli menurut Al-Sunnah, dapat dilihat dari Hadits Riwayat al-Bazar dalam kitab Bulughul Maram hadits ke-800, tentang disyari'atkannya jual beli dan keutamaanya, dari Rifa'ah ibn Rafi r.a bahwa

\footnotetext{
${ }^{43}$ Ghoffar.

${ }^{44}$ Ghoffar.

${ }^{45}$ Akbar Musfira dan Ambo, "Analisis Tingkat Kecurangan dalam Takaran dan Timbangan bagi Pedagang Terigu (Studi Kasus di Pasar Sentral Maros)."
} 
Rasulullah SAW pernah ditanya mata pencaharian apa yang paling bagus dan beliau menjawab pekerjaan seseorang dengan tangannya dan tiap-tiap jual beli yang baik. Kandungan hadist diatas adalah Rasulullah sangat melarang sikap dan perilaku negatif dalam aktivitas jual beli, selain itu juga dorongan untuk mencari kerja yang halal dan berbuat untuk tujuan yang mulia, sertas hadits diatas menerangkan bahwa profesi yang baik adalah profesi dengan tangan, dalam hal ini dagang termasuk paling baik, syaratnya bersih dari transaksi haram seperti riba, penipuan ataupun yang lainnnya ${ }^{46}$.

Kedua, hadits riwayat Muslim, dalam kitab Bulughul Maram hadits ke836, tentang larangan menipu dalam jual beli, dari Abu Hurairah bahwasanya Rasulullah pernah melewati tumpukan makanan lalu memasukkan tangannya kedalam tumpukan makanan tersebut, lalu jari-jarinya basah. Lalu beliau bersabda apakah ini wahai pemilik makanan, lalu pemilik makanan menjawab bahwa makanan itu terkena hujan. Dan rasulullah bersabda bahwa mengapa tidak diletakkan diatas agar dapat dilihat orang, sebab barang siapa menipu ia tidak termasuk umatku. Isi kandungan hadits diatas adalah pertama, bahwa menurut ijma para ulama haram menipu dalam jual beli dan muamalah lainnya, seorang muslim harus paling baik dalam muamalahnya dan paling jauh dari menipu dan berkhianat. Kedua, boleh menjual benda buruk atau cacat jika diperlihatkan. Ketiga, diketahui oleh pembeli dan pembeli mau membelinya ${ }^{47}$.

Ketiga, hadits riwayat Muslim dalam kitab Bulughal Maram hadits ke816, tentang larangan jual beli gharar, dari Abu Hurairah r.a. ia berkata bahwa Rasulullah melarang jual beli dengan cara melempar batu dan jual beli gharar (Yang belum jelas harga barang, waktu dan tempatnya. Isi kandungan hadits tersebut adalah pertama, diharamkan jual beli hashas (melempar), dengan cara apapun, hal ini disebabkan adanya ketidakjelasan harga atau benda yang dijual. Kedua, diharamkan menipu dan ketidakjelasan dalam jual beli, sebab hal demikian dapat menyebabkan salah satu pihak tidak rela (ridha) jika terjadi. Oleh karena itu maka terjadilah memakan harta orang lain dengan cara salah yakni yang diharamkan oleh syara. Ketiga, ketidakjelasan dalam jual beli dapat terjadi jika benda yang dijual tidak ada, atau tidak diketahui, atau penjual tidak mampu menyerahkan atau mengaku-ngaku miliknya, namun hak miliknya tidak seutuhnya miliknya artinya hak miliknya tidak sempurna. Seperti menjual ikan di air banyak. Keempat, Menurut jumhur ulama, ketidakjelasan yang mungkin dapat dihindari maka dimaafkan, seperti

\footnotetext{
${ }^{46}$ Al-Hafizh ibnu Hajar Al Asqalani, Bulughul Maram (Bandung: Darul Kitab al-Arabiah indonesia, 1448).

${ }^{47}$ Al-Hafizh ibnu Hajar Al Asqalani.
} 
tidak tahu pondasi rumah. Demikian juga ketidakjelasan yang ringan karena diperlukan, itupun dimaafkan. Misalnya menjual benda yang berada dibawah tananh, seperti bawang dan sejenisnya. Kelima, menurut ijma para ulama, tidak sah menjual janin didalam kandungan dan burung di udara ${ }^{48}$.

Keempat, hadits yang diriwayatkan oleh Bukhari Muslim (Mutafaq 'alaih), dalam kitab Bulughal Maram hadits ke 805, tentang pelarangan bagi orang yang bangkrut atau pailit untuk mengelola keuangannya, dari Jabir bin Abdillah r.a. dia berkata bahwa seseorang diantara kami ada yang berwasiat memerdekakan hamba miliknya setelah ia meninggal dunia, padahal ia tidak memiliki harta kecuali budak tersebut. Maka Rasulullah memanggil budak tersebut lalu menjualnya. Isi kandungan hadits ini adalah pertama, boleh menjual budak mudabbar yang merdekanya digantungkan pada kematian pemiliknya demi kemaslahatan pemilik. Kedua, seseorang boleh menawar lebih tinggi ketika jual beli. Ketiga, boleh menahan orang pailit dan menjual harta bendanya tanpa kerelaan demi kepentingannya ${ }^{49}$.

Kelima, hadits yang diriwayatkan oleh Bukhari dalam kitab Bulughul Maram hadits ke-826, dalam hadits tersebut dijelaskan bahwa Rasulullah SAW, mengharamkan jual beli dengan cara muhaqalah (menjual biji atau tanaman dengan borongan yang masih samar ukurannya), muhadharah (menjual biji-bijian atau buah-buahan yang belum masak yang belum tentu bisa dimakann), mulamasah (menjual barang dengan cara hanya diraba), munabadzah (menjual barang dengan saling lempar) dan muzabanah (menjual buah yang masih segar dengan yang kering dengan sukatan), selain itu dalam hadits tersebut dijelaskan haram menjual buah sebelum tampak kelayakannya, maksud dari tampak kelayakannya adalah buah sampai pada batas dimana ia bisa memanfaatkan meskipun belum keras dan berwarna khusus, jika buah sampai pada batas tersebut, maa buah boleh dijual dengan syarat dipotong. Sedangkan menurut ijma ulama, tidak boleh hukumnya jika buah masih ada di pohon, selain itu juga sah menjual buah setelah tampak layak, yakni bijiny keras dan sudah mencapai warna khusus secara mutlak ${ }^{50}$.

\section{2) Dasar Hukum Halalan Thayyiban \\ a) Halalan Toyyiban perspektif Al-Quran}

\footnotetext{
${ }^{48}$ Al-Hafizh ibnu Hajar Al Asqalani.

${ }^{49}$ Al-Hafizh ibnu Hajar Al Asqalani.

${ }^{50}$ Al-Hafizh ibnu Hajar Al Asqalani.
} 
Pertama, dasar hukum halalan thayyiban, surat Al-Baqarah $29^{51}$ dan kedua, Q.S. Al-Jatsiyah $13^{52}$. Menurut Quraish Shihab, para ulama berkesimpulan bahwa pada prinsipnya segala sesuatu yang ada di alam raya ini adalah halal untuk digunakan, sehingga makanan yang terdapat di dalamnya juga halal. Karena itu dengan tegas Al-Qur'an mengecam orang-orang yang mengharamkan rizki yang telah Allah hamparkan untuk manusia. Pengharaman segala sesuatu harus bersumber dari Allah, baik melalui Al-Qur'an maupun Rasul. Pengharaman timbul dari kondisi manusia. Mengingat ada di antara makanan yang dapat memberi dampak negatif terhadap jasmani manusia ${ }^{53}$.

Ketiga, menurut tafsir ibnu katsir bahwa surat al-Baqarah ayat $172^{54}$ $173^{55}$, menjelaskan Allah swt. memerintahkan hamba-Nya yang beriman agar memakan makanan yang baik dari rizki yang telah dianugerahkan kepadanya, agar mereka bersyukur kepada-Nya atas rizki atas rizki yang telah diberikannya itu. Memakan makanan yang halal merupakan salah satu sebab terkabulnya do'a dan diterimanya ibadah. Sebagaimana memakan makanan yang haram menghalangi diterimanya do'a dan ibadah. Setelah Allah menganugerahkan rezeki-Nya kepada mereka dan membimbing mereka agar memakan makanan yang baik, Allah juga memberitahukan bahwa Dia tidak mengharamkan makanan-makanan itu kecuali bangkai saja, yaitu binatang yang mati dengan sendirinya, tanpa disembelih. Selain itu, Allah juga mengharamkan daging babi, baik yang disembelih maupun yang mati dengan sendirinya. Lemak babi termasuk dalam hukum dagingnya, karena secara generalisasi, atau karena dagingnya mengandung lemak, atau melalui cara qiyas (analogi) menurut suatu pendapat ${ }^{56}$.

Allah Ta'ala juga mengharamkan kepada mereka binatang yang disembelih dengan menyebut nama selain nama Allah, baik itu dengan mengatas namakan berhala, sekutu, tandingan, dan lain sebagainya, yang dahulu menjadi kebiasaan orang-orang Jahiliyah untuk mempersembahkan korban kepadanya. Dalam ayat tersebut dijelaskan barangsiapa dalam keadaan terpaksa (memakannya) sedang tidak menginginkannya dan tidak

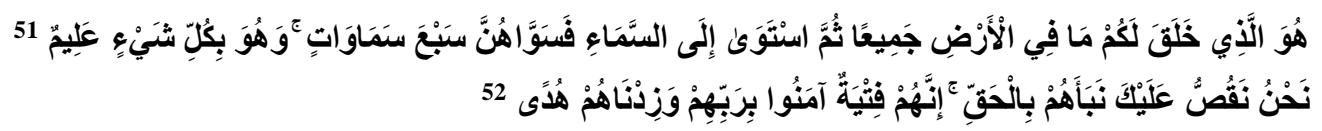

53 Al-Wasim Arif, "Label Halal dan Hukum Asal Bahan Pangan."

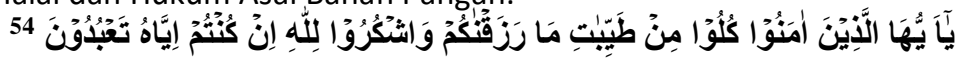

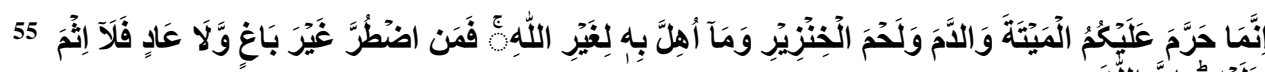

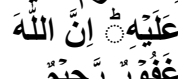

${ }^{56}$ Ghoffar, Tafsir Ibnu Katsir Jilid 2. 
pula melampaui batas, ini berarti tidak dalam keadaan merampok, atau keluar dari ketaatan imam atau bepergian dalam kemaksiatan kepada Allah, maka mendapatkan keringanan. Tetapi orang yang melampaui batas atau melanggar, atau dalam kemaksiatan kepada Allah, maka tidak ada keringanan baginya, meskipun berada dalam keadaan terpaksa. Selain itu dalam mengkonsumsinyapun tidak boleh melampaui batas melebihi makanan yang halal. Menurut ibnu abbas, arti dari tidak melampaui batas itu tidak sampai kenyang memakannya. Tetapi as-Suddi menafsirkannya dengan tidak melampau batas itu adalah tidak melanggar (batas). Selain itu, jika tidak makan dan tidak minum lalu meninggal dunia, maka ia masuk neraka. Ini menunjukkan bahwa memakan bangkai bagi orang yang dalam keadaan terpaksa merupakan azimah (keharusan) dan bukan sekedar rukshah (keringangan) $)^{57}$.

\section{b) Halalan Tayyiban Perspektif Al-Sunnah}

Pertama, dalam Hadits yang diriwayatkan Thabrani dalam kitab AlAusath dengan isnad hasan, dalam kitab Bulughul Maram hadits ke-837, hadits tersebut menjelaskan bahwa menurut ijma ulama, haram hukumnya menjual anggur basah secara sengaja kepada orang yang menjadikan anggur tersebut menjadi minuman keras. Selain itu hadits tersebut menjelaskan diharamkan menjual sesuatu yang dapat membantu maksiat. Misalnya seruling, alat musik, serta menyewakan toko, gedung atau hotel untuk prostitusi dan untuk berbuat maksiat ${ }^{58}$.

Kedua, didalam hadits riwayat Bukhari Muslim (Mutafaq 'alaih) dalam kitab Bulughul Maram hadits ke 801, tentang larangan jual beli arak, bangkai, babi, dan patung, dari Jabir bin Abdillah r.a. bahwasanya Rasulullah bersabda di mekah tepatnya ketika penaklukan kota mekah, Allah telah mengharamkan jual beli arak, bangkai, babi dan patung, lalu beliau ditanya perihal lemak bangkai, sebab lemak bangkai dapat digunakan untuk mengecat perahu, meminyaki kulit dan untuk menyalakan lampu, lalu beliau menjawab bahwa itu (lemak bangkai) haram, dan Rasulullahpun bersabda semoga Allah melaknat orang-orang yahudi karena Allah telah mengharamkan atas mereka jual beli lemak bangkai dengan cara mereka memproses lemak itu, kemudian mereka jual dan memakan hasilnya. Isi kandungan hadits diatas menerangkan bahwa pertama, haram menjual arak, bangkai, babi dan berhala. Kedua, menurut jumhur ulama boleh menjual bulu bangkai baik halus ataupun kasar sebab tidak termasuk kategori bangkai.

\footnotetext{
${ }^{57}$ Ghoffar.

${ }^{58}$ Al-Hafizh ibnu Hajar Al Asqalani, Bulughul Maram.
} 
Ketiga, boleh menjual berhala jika dihancurkan. Keempat, boleh memanfaatkan bangkai untuk selain dijual, sebab dhamir dalam sabda nabi: "Tidak itu haram" kembali kepada jual beli, sebagaimana ijma ulama bahwa halal memberi anjing dengan bangkai, meskipun anjing itu untuk berburu. Selain itu ada juga pendapat yang mengatakan bahwa haram menggunakan bangkai secara mutlak, sebab dhamirnya kembali kepada memanfaatkan. Kelima, jika Allah telah mengharamkan memakan sesuatu maka harga benda itu juga haram. Keenam, bahwa rekayasa terhadap haram adalah perbuatan yahudi, sedangkan segala udaha untuk menghalalkan yang haram adalah batal ${ }^{59}$.

\section{SIMPULAN}

Menurut Islam bahwa jual beli yang halalan tayyiban itu menjadi suatu keharusan, sebab halalan thayyiban itu merupakan bagian dari syarat jual beli. Selain itu juga jika transaksi jual belinya tidak halal dan baik maka jual belinya menjadi ghair shahih atau bathil, sehingga karena jual belinya bathil maka jual beli tersebut dilarang Allah, dan secara otomatis jual belinya tersebut tidak mendapatkan ridha dan keberkahan dari Allah. Adapun dasar hukum Islam harus melakukan transaksi jual beli dengan halalan thayyiban yaitu surat alBaqarah ayat 172-173 serta hadits riwayat Bukhari Muslim (Mutafaq 'alaih) dalam kitab Bulughul Maram hadits ke 801, tentang larangan jual beli arak, bangkai, babi, dan patung.

\section{Daftar Pustaka}

Achmad Sunarto. "Ensiklopedi Tematis Ayat Alquran Dan Hadits Jilid 7."

Dalam Tematis, 10. Widya Cahaya Jakarta, 2016.

Akbar Musfira, dan Asse Ambo. "Analisis Tingkat Kecurangan dalam Takaran dan Timbangan bagi Pedagang Terigu (Studi Kasus di Pasar Sentral Maros)," 2017.

Al-Hafizh ibnu Hajar Al Asqalani. Bulughul Maram. Bandung: Darul Kitab alArabiah indonesia, 1448.

Al-Wasim Arif. "Label Halal dan Hukum Asal Bahan Pangan." Studi Al-Quran dan Hukum 2, no. 2 (2017): 311-26.

Darmawati. "Perilaku Jual Beli di Kalangan Pedagang Kaki Lima dalam

Perspektif Etika Bisnis Islam." Fenomena IV, no. 2 (2012).

Djuaedi, Wawan. Fiqih. Jakarta: Lista Farista Putra, 2008.

\footnotetext{
${ }^{59}$ Achmad Sunarto, "Ensiklopedi Tematis Ayat Alquran Dan Hadits Jilid 7," dalam Tematis (Widya Cahaya Jakarta, 2016).
} 
Fhatoni Nur. "Konsep Jual Beli dalam Fatwa DSN-MUI." Konsep Jual Beli Dalam Fatwa DSN-MUI IV (2013).

Ghoffar, M. Abdul. Tafsir Ibnu Katsir Jilid 2. Bogor: Pustaka Imam Asy-Syafi'i, 2004.

Ghufron Ihsan. Fiqh Muamalat. Jakarta: Prenada Media Grup, 2008.

Hendiana Runto, dan Ahmad dasuki Ali. "Transaksi Jual Beli Online dalam

Perspektif Hukum Islam." Al-mushtasfha 3, no. 2 (2016).

Imam Jalaludin As-Suyuti, dan Imam Jalaludin Al-Mahalli. Tafsir Jalalain.

Bandung: Sinar Baru Algensindo, 2003.

Lahaling Hijrah, Makkulawuzar Kindom, dan Rukka Singkeru. "Labelisasi

Haram terhadap Perlindungan Konsumen." Hasanuddin Law Review 1,

no. 2 (2015).

Makki Hali. "Persfektif Hukum Islam terhadap Hak Arisan di Desa Kropoh

Sumenep." istidlal 1, no. 1 (2017).

Mulyani, Endang. Ringkasan Eksekutif Hasil Survei Penyahgunaan dan

Peredaran Gelap Narkoba pada Kelompok Pelajar dan Mahasiswa

Tahun 2016 (2016).

Muttaqin Azhar. "Transaksi E-Comerce dalam Tinjauan Hukum Jual Beli

Islam." ulumuddin VII, no. 1 (2013).

Nasrun Haroen. Fiqih Muamalah. jakarta: Gaya Media Pratama, 2007.

Negeri, Pusat Pengkajian Perdagangan Luar. "Laporan Analisis Impor Produk

Minuman Beralkohol Melalui Pelabuhan Tertentu." Jakarta, 2016.

Nurjannah, dan Juju Jumena. "Praktek Jual Beli Kain Kiloan dalam Perspektif

Hukum Islam." Al-Mustashfa 3, no. 2 (2016).

Rachmawati, Ira. "buwas pengguna narkoba meningkat hingga 5,9 juta orang." kompas.com. 2016.

Rozalinda. Fiqih Ekonomi Syariah. Jakarta: Raja Grafindo Persada, 2015.

Sabiq Sayyid. fiqih sunnah, juz 3, 1983.

santosa, purbayu budi, Muttaqin, dan aris anwaril. "Larangan Jual Beli

Gharar ; Telaah dari Musnad Ahmad bin Hanbal." Ekonomi Syariah 3, no. 1 (2015): 157-73.

Shobirin. "Jual Beli Dalam Pandangan islam." Jual Beli dalam Pandangan Islam 3 (2015): 2.

Sudirman, dan Dahlan Tamrin. "Urgensi Labelisasi Halal di Tingkat Lokal." ElQudwah, 2012.

Syafe'i Rachmat. Fiqih Muamalah. Bandung: Pustaka Setia, 2000.

Syaifullah. "Etika Jual Beli Dalam Islam." Etika Jual Beli Dalam Islam 11 (2014):

2.

Waluyo. "Pengaruh Pemahaman Agama, Motivasi Mendapatkan Profit,Tingkat Pendidikan terhadap Kesadaran Sertifikat Halal bagi 
Produsen di Kabupaten Sleman Bantul." Inferensi VII, no. 1 (2013): 75-98.

Widyaningrum, dan Premi Wahyu. "Pengaruh Label Halal dan Celebrity Endorser terhadap Keputusan Pembelian." Ekonomi Syariah Indonesia VI, no. 12 (2016).

Zuhaily, Wahbah. al-Figh al-Islam wa Adillatuh, juz 4, 1984.

Zumar Muhammad. "Sertifikat Halal Studi Perbandingan Indonesia dengan Thailand." Shahih: Journal of Islamicate Multidisciplinary 1, no. 1 (2016). 